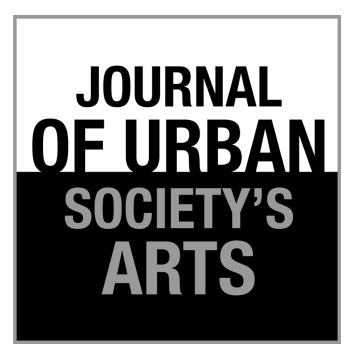

Volume 2 Nomor 1, April 2015: 9-17

\section{Perkembangan dan Perubahan Tepak Kendang Jaipongan Suwanda dalam Masyarakat Urban}

\section{Asep Saepudin}

Jurusan Karawitan, Fakultas Seni Pertunjukan, Institut Seni Indonesia Yogyakarta E-mail: sepskd@gmail.com; HP: 081227978377

\begin{abstract}
ABSTRAK
Tulisan ini membahas perkembangan tepak kendang jaipongan karya Suwanda dilihat dari kontinuitas dan perubahannya terutama yang terjadi dalam masyarakat urban. Metode deskriptif analisis dengan pendekatan sejarah digunakan untuk mengungkap berbagai fenomena tepak kendang jaipongan, yaitu hadirnya notasi yang dibuat oleh para pengendang dan perubahan tepak kendang jaipongan dalam struktur, tempo, dinamika, embat, motif, serta fungsi. Berdasarkan hasil analisis dapat disimpulkan bahwa tepak kendang jaipongan karya Suwanda pada perkembangannya ditanggapi secara kreatif oleh para pengendang melalui kreativitasnya. Oleh karena itu, terdapat perbedaan motif tepak kendang antara hasil rekaman Suwanda di dalam kaset dengan fakta di lapangan ketika digunakan oleh para pengendang. Hal ini menyebabkan terjadinya perubahan dan kepunahan beragam tepak kendang jaipongan karya Suwanda di masyarakat.
\end{abstract}

Kata kunci: Suwanda, tepak, kendang, jaipongan

\begin{abstract}
The Development and Changes of Suwanda's Tepak Kendang Jaipongan in Urban Society. This paper discusses the development of Suwanda's tepak kendang jaipongan, drumming strokes of jaipongan, seen from its continuity and changes, particularly for what has been found in urban society. The descriptive analysis method with historical approach is used to explore any various kind of phenomenon of drumming strokes of jaipongan, among others are the presence of jaipongan notation created by the drummers as well as the changes in the structure of drumming strokes of jaipongan, tempo, dynamics, embat, motifs, and function. Based on the analysis it can be concluded that the Suwanda's drumming strokes of jaipongan in its progress has been creatively responded by the drummers through their creativity. Therefore, there is a significant difference between the motives of Suwanda's drumming strokes recorded on tape with the facts of live performance when they are used by the drummers. This led to the change and the extinction of various Suwanda's jaipongan drumming strokes in the community.
\end{abstract}

Keywords: Suwanda, strokes, drum, jaipongan

\section{Pendahuluan}

Perkembangan tepak kendang jaipongan karya Suwanda belakang ini telah mengalami banyak perubahan setelah digunakan lebih dari tiga puluh tahun oleh para seniman. Tepak kendang jaipongan pada masa sekarang tidak sama lagi dengan tepak kendang jaipongan pada masa Suwanda. Pada masa sekarang ini banyak bermunculan pola-pola baru hasil kreativitas para seniman 
muda. Tepak kendang jaipongan karya Suwanda mulai tidak cocok lagi dengan tuntutan pasar dan realitas masyarakat pada masa kini. Oleh karena itu tidak mengherankan seandainya tepak kendang jaipongan banyak yang berubah bahkan terdapat motif yang hilang dimana tidak digunakan lagi oleh para pengendang. Tepak kendang jaipongan telah mengalami berbagai perubahan seperti dalam tempo, struktur, dan motif tepak kendangnya.

Pada masa sekarang telah terjadi transformasi tepak kendang jaipongan Suwanda setelah beredar dan ditiru selama tiga puluh tahun lebih oleh para seniman. Transformasi yang dimaksud adalah telah terjadinya perubahan struktur gramatikal menjadi struktur gramatikal lain dengan menambah, mengurangi, dan menata kembali (KBBI, 2005: 1209) pola-pola tepak kendang jaipongan oleh generasi berikutnya. Dampaknya, motif-motif tepak kendang Suwanda banyak yang tidak berlaku lagi di antara para seniman karena motif-motif yang digunakan pada masa sekarang adalah motif-motif baru hasil kreativitas para pengendang meskipun secara bentuk masih nampak dari bentuk tepak kendang Suwanda.

Berdasarkan pemaparan tersebut maka tujuan penulisan ini untuk memberikan informasi secara komprehensif mengenai perkembangan tepak kendang jaipongan Suwanda dilihat dari kontinuitas dan perubahannya terutama yang terjadi dalam masyarakat urban. Di dalamnya dibahas pula tentang perubahan struktur tepak kendang jaipongan dan diungkap tentang dampak dari realitas kebutuhan yang ada di masyarakat terhadap hasil kreativitas seniman dalam menggarap tepak kendang jaipongan.

\section{Suwanda sebagai Pencipta Tepak Kendang Jaipongan}

Menulis tepak kendang jaipongan tidak lepas dari Suwanda sebagai pelaku seninya. Informasi biografis Suwanda dapat dilihat dari latar belakang lingkungan sosio-kulturalnya, proses pendidikan formal dan informal, watak-watak orang yang ada di sekelilingnya, cara persepsi dan konsepsinya, pandangan hidup, dan orientasi intelektualnya (Kartodirdjo, 1992:77). Suwanda adalah seorang seniman pengendang yang menciptakan tepak kendang jaipongan. Suwanda lahir pada 03 Maret 1950 di Citopéng, Bolang, Batu Jaya, Rengasdéngklok, Karawang, Jawa Barat. Suwanda merupakan keluarga seniman yang mewariskan kesenian topéng banjét secara turun-temurun. Topéng banjét menurut Soepandi (1999:74), termasuk salah satu bentuk pertunjukan sandiwara rakyat yang terdapat di daerah Bekasi, Karawang, Subang, dan Bogor.

Pengalaman berkesenian selama bertahuntahun membentuk Suwanda menjadi seniman yang handal dalam memainkan instrumen kendang. Pengalaman berkesenian diperolehnya saat berada dalam kesenian topéng banjét, baik dalam grup ayahnya maupun ketika mengikuti grup lain yang berada di Karawang. Selama kurang lebih sebelas tahun lamanya yakni dari 1966 sampai dengan 1977, Suwanda mencari ilmu menabuh kendang dengan memasuki beberapa grup topéng banjét yang berada di Karawang yakni grup topéng banjét Abah Reman, topéng banjét Abah Pendul, topéng banjét Wadas, serta topéng banjét Baskom (Saepudin, 2010:165-168).

Hasil penyadapan dari berbagai grup tersebut memberi pengaruh sangat besar bagi Suwanda untuk mampu menciptakan beragam tepak kendang jaipongan sebagai tepak baru dalam karawitan Sunda pada tahun 1980-an. Pola tepak kendang karya Suwanda di antaranya tepak kendang dalam lagu Daun Pulus Késér Bojong, Serat Salira, Banda Urang, Bulan Sapasi, Seunggah, IringIring Daun Puring, dan Toka-Toka, Daun Pulus Mimiti, Daun Pulus Panineungan, Daun Pulus 1 sampai Daun dengan Pulus 20, Daun Pulus Adu Manis, Tepung di Luhur Panggung. Hasil karya tersebut merupakan tepak kendang jaipongan yang diciptakan Suwanda pada tahun 1980-an yang merupakan masa kejayaan jaipongan dalam seni pertunjukan di Jawa Barat. Pada masa tersebut menjadi tidak mengherankan seandainya Suwanda menjadi ikon dalam tepak kendang jaipongan.

\section{Kemunculan Tepak Kendang Jaipongan}

Tepak kendang jaipongan lahir berawal dari pertemuan Suwanda dengan Gugum Gumbira, seorang seniman berasal dari Bandung, Jawa 
Barat. Gugum sangat membutuhkan pengendang yang dapat memahami dan mengikuti ide-ide kreatif untuk mengiringi tari yang dibuatnya. Ketertarikan Gugum terhadap tepak kendang improvisasi yang terdapat dalam kesenian topéng banjét, mengantarkan Gugum untuk bertemu dengan Suwanda, seorang pengendang topéng dari Karawang, Jawa Barat.

Suwanda dan Gugum saling menjajaki keterampilan yang dimiliki masing-masing. Suwanda ternyata dapat memuaskan Gugum dengan ketangkasan tepak kendangnya. Kehadiran Suwanda bukan saja memuaskan Gugum, tetapi menjadi pemecah persoalan para pengrawit ketika itu yang sedang kesulitan mengikuti ide-ide Gugum. Para pengrawit belum bisa memenuhi seluruh keinginan Gugum untuk membuat garapan yang baru. Hal ini disebabkan para pengrawit masih kesulitan untuk keluar dari konvensi atau pakem tradisi yang telah dimiliki selama bertahun-tahun dalam melakukan kegiatan seninya.

Setelah terdapat kesamaan persepsi antara Suwanda, Gugum, dan para pengrawit, mulailah disusun beragam tepak kendang jaipongan. Dalam hal ini terjadi kompromi di antara para pengrawit. Kompromi yang dimaksud adalah kesepakatan garapan yakni dari goong ka goong (goongan ke goongan). Goongan menjadi aturan bersama untuk menyamakan persepsi antara tepak kendang, gending, dan tarian. Kesepakatan tersebut menghasilkan karya-karya jaipongan sebagai karya baru pada tahun 1980-an. Karya-karya ini menjadi awal lahirnya beragam tepak kendang jaipongan. Suwanda berhasil melahirkan beragam tepak kendang jaipongan yang kaya variatif, dan energik sehingga mampu mewadahi gerak-gerakan tari yang dibuat oleh Gugum Gumbira. Dalam hal ini tahun 1980-an merupakan tahun kejayaan jaipongan dalam karawitan Sunda Jawa Barat.

\section{Bentuk dan Struktur Kendang Jaipongan}

Bentuk tepak kendang jaipongan masih mengacu pada konsep tradisi sebelumnya yakni goongan sebagai dasar pijakan tepak kendangnya. Goong ka goong lahir karena konsep kompromi yang dijalankan antara penata karawitan dan penata tari pada awal penciptaannya. Dalam satu pola lagu jaipongan memiliki beberapa goongan dari setiap ragam tepaknya. Goongan inilah yang menjadi acuan, batasan, dan bagian-bagian penting yang dapat dijadikan konsep bersama dalam menabuh kendang jaipongan. Dalam setiap goongan terdiri dari beberapa tepak di antaranya tepak bukaan, tepak pangjadi, tepak mincid, dan tepak ngeureunkeun. Masing-masing memiliki ragam tepak yang berbeda dalam setiap goongannya. Dalam tepak bukaan terdiri dari ragam tepak bukaan, pencugan, seredan, cindek, ngagoongkeun. Dalam tepak mincid terdiri dari ragam tepak mincid kendor, ragam tepak mincid gancang, dan ragam tepak peralihan atau ragam tepak ngala.

Dalam setiap pola tepak kendang jaipongan secara umum dibagi menjadi tiga bagian yakni angkatan wirahma (awal), tataran wirahma (tengah), dan pungkasan wirahma (akhir). Bagian angkatan wirahma umumnya diisi oleh tepak pangkat (buka: dalam karawitan Jawa), tataran wirahma oleh tepak pangjadi, bukaan dan mincid, sedangkan bagian pungkasan wirahma oleh tepak ngeureunkeun (memberhentikan). Setiap bagian tepak tersebut memiliki ragam tepak yang berbeda (memiliki banyak motif) sehingga para seniman sering memainkan pola kendang yang berbeda meskipun dalam satu lagu yang disajikan.

Struktur pokok tepak kendang jaipongan Suwanda secara umum dapat dibagi menjadi lima bagian yakni pangkat, pangjadi, bukaan, mincid, dan ngeureunkeun atau A, B, C, D, E. Kelima struktur pokok ini memiliki berbagai variasi bergantung pada lagu dan tarian yang disajikan. Oleh karena itu, setiap lagu memiliki struktur yang berbeda sesuai dengan kebutuhannya sehingga memiliki ciri khas antara lagu yang satu dengan lagu yang lain.

\section{Tepak Kendang Jaipongan di Masyarakat Urban}

Setelah tepak kendang jaipongan karya Suwanda direkam dalam bentuk kaset, ternyata kehadirannnya diterima dengan baik oleh masyarakat Jawa Barat meskipun pada awalnya menuai banyak kritikan. Tepak kendang jaipongan yang pada awalnya dikerjakan secara improvisasi, akhirnya menjadi terpola, terstruktur, bahkan menjadi 
baku setelah direkam dalam bentuk kaset. Oleh karena itu, tepak kendang jaipongan Suwanda di dalam kaset, banyak dijadikan sarana belajar bagi para seniman, baik seniman tari maupun karawitan di berbagai daerah. Para remaja putri belajar tari jaipongan dari kaset, para pangrawit belajar gending jaipongan, para pengendang belajar tepak kendang jaipongan, perangkat gamelan degung diganti laras menjadi laras saléndro untuk mengiringi tari jaipongan. Sanggar jaipongan berdiri di manamana, pertunjukan jaipongan semarak di setiap daerah, seniman jaipongan semakin bertambah. Berbagai jenis kesenian sebagai sumber penciptan tepak kendang jaipongan pada akhirnya terpengaruh oleh tepak kendang jaipongan. Tepak kendang jaipongan masuk dalam kesenian kiliningan, bajidoran, dan wayang golék. Kehidupan seni pertunjukan Jawa Barat menjadi hidup, semarak dengan hadirnya jaipongan. Jaipongan yang pada awalnya termasuk kategori seni pertunjukan rakyat, bergeser menjadi pertunjukan populer karena digemari oleh masyarakat, baik di kota maupun di desa (Narawati dan Soedarsono, 2005:30). Pergeseran jaipongan menjadi pertunjukan popular karena keberadaannya didukung oleh masyarakat setempat (community support) (Brandon, 2003:251-274).

Terdapat dua fenomena keberadaan tepak kendang jaipongan yang terjadi di masyarakat setelah direkam dalam bentuk kaset. Kedua fenomena tersebut adalah: pertama, ragam tepak kendang jaipongan hasil karya Suwanda terdapat dalam kaset rekaman, terjual bebas di pasaran, menyebar luas di masyarakat. Pola dan ragam tepak yang terdapat di dalam kaset sifatnya tetap, apa adanya dari hasil rekaman, tidak mengalami perubahan dalam berbagai hal seperti dalam tempo, urutan, waktu, dan ragam tepak; kedua, ragam tepak kendang jaipongan karya Suwanda ditiru oleh para seniman di berbagai daerah. Beragam tepak kendang jaipongan dikuasai oleh para pengendang Sunda selain Suwanda untuk pentas di panggungpanggung pertunjukan di seluruh pelosok daerah Jawa Barat. Dalam fenomena ini, tepak kendang jaipongan memiliki berbagai perubahan dalam tempo, urutan, durasi, dan ragam tepak.

Fungsi tepak kendang jaipongan setelah terbentuk dan digunakan oleh masyarakat, sebenarnya masih sama dengan fungsi ketika dibuat oleh Suwanda yakni untuk mengiringi lagu, tari, dan gending serta sebagai pemenuhan kebutuhan pasar. Dalam fungsi art for art, tepak kendang jaipongan untuk mengiringi tari lebih mendominasi di arena pertunjukan terutama yang fungsinya untuk hiburan. Pengendang jaipongan lebih banyak mengiringi tarian daripada lagu. Sebagai alasannya adalah karena tepak, lagu, dan gending jaipongan sudah terbentuk utuh. Para seniman tinggal menggunakannya sesuai dengan apa yang ada dalam kaset, baik penari, koreografer, pangrawit, maupun pengendang. Art for mart yaitu bahwa hadirnya jaipongan terutama tepak kendang menjadi konsumen masyarakat penikmat sehingga tuntutan pasar semakin meningkat. Para produser berebut merekam jaipongan karena permintaan pasar meningkat. Pertunjukan jaipongan menyebar di mana-mana serta memberikan penghasilan bagi para seniman (baik penari maupun pangrawit) di berbagai daerah.

Pada awal penciptaan ragam tepak kendang jaipongan yang dibuat oleh Suwanda tidak dipola terlebih dahulu serta tidak ada pola baku sebelum rekaman namun lebih merupakan hasil improvisasi dengan mengandalkan konsep kebebasan. Ciri dari improvisasi Suwanda adalah ragam tepaknya banyak, variatif, berbeda setiap lagu, dan tidak ada notasi khusus yang dibuat oleh Suwanda dalam ragam tepak kendangnya. Pada masa sekarang ini tidak ada satu lagu pun notasi kendang jaipongan yang dimiliki Suwanda dalam setiap ragam tepak kendangnya. Tepak kendang jaipongan betul-betul merupakan hasil improvisasi seorang pengendang yang sudah memiliki banyak referensi tepak dalam dirinya.

Suwanda meski sebagai pencipta tepak kendang jaipongan tidak memiliki notasi dan hal ini sangat berlainan dengan yang terjadi di luar Suwanda. Para pengendang jaipongan selain Suwanda (seniman praktisi dan akademis), memiliki notasi untuk tepak kendang jaipongan. Pengendang di luar Suwanda berusaha meniru beragam tepak kendang jaipongan yang dibuat oleh Suwanda karena berbagai kepentingan, misalnya untuk mengajar di sekolah, mengajar pada murid, atau untuk mengiringi para penari 
dalam tarian jaipongan di panggung pertunjukan. Salah satu penyebab berkembangnya notasi kendang jaipongan di para pengendang di Jawa Barat karena tuntutan untuk sama persis dengan kaset yang direkam oleh Suwanda.

Notasi kendang jaipongan memiliki dua versi yaitu notasi kendang jaipongan versi sekolah seni seperti yang digunakan di STSI Bandung dan SMKN 10 Bandung serta notasi kendang versi para pengendang praktisi. Kedua notasi ini digunakan oleh para pengendang untuk mengiringi tarian jaipongan. Para pengendang berusaha meniru beragam tepak kendang Suwanda dalam lagu-lagu yang beredar luas di masyarakat. Notasi kendang yang berkembang di antara para seniman memiliki multitafsir. Pengendang di luar Suwanda membuat notasi kendang jaipongan berdasarkan pemahaman masing-masing terhadap ragam tepak Suwanda yang terdapat dalam kaset. Satu lagu karya Suwanda misalnya dalam ragam tepak kendang jaipongan lagu Seunggah, memiliki notasi dan peristilahan yang berbeda. Ragam tepak kendang Suwanda ditafsirkan menjadi beberapa nama yang berbeda meskipun maksudnya sama. Hadirnya notasi kendang jaipongan merupakan bagian kreatif para pengendang untuk menyesuaikan dengan keperluan dan permintaan pasar dalam menjalankan kegiatan seninya.

Ragam tepak kendang jaipongan yang telah direkam dalam kaset mengalami pengolahan kembali oleh para pengendang lain ketika digunakan dalam panggung pertunjukan sehingga banyak yang berubah. Perubahan tersebut terjadi karena kepentingan tarian pada waktu pentas serta adanya kreativitas dari para pengendang untuk mengembangkan beragam tepak kendang yang telah ada dalam kaset. Di panggung pertunjukan, sering terjadi kompromi antara pengendang dan penari sesaat sebelum pementasan. Pengendang dan penari menyepakati terlebih dahulu gerakan dan tepak kendang yang akan dimunculkan di atas panggung. Perubahan terjadi pula karena adanya respons pengendang terhadap gerakgerak improvisasi dari penari saat di panggung pertunjukan. Pengendang biasanya selalu mengikuti gerak-gerak penari di panggung sehingga secara tidak langsung data membentuk motif yang baru jika hal tersebut dilakukan secara berulang-ulang.

\section{Perubahan Tepak Kendang Jaipongan}

Masyarakat Sunda yang umumnya jauh dari istana memberi pengaruh sangat besar terhadap cara menyikapi perubahan-perubahan yang senantiasa hadir dalam kehidupan. Dalam bidang kesenian, para seniman Sunda lebih terbuka dalam menerima setiap perubahan yang ada di masyarakat meskipun memiliki dampak positif dan negatif. Dampak positifnya adalah menghasilkan perubahan dalam berbagai jenis kesenian sehingga menghasilkan karya-karya baru yang atraktif dan dinamis yang dibutuhkan masyarakat pada setiap zamannya. Dampak negatifnya adalah musnahnya beberapa jenis kesenian yang ada di masyarakat. Hal ini terjadi karena masih tidak imbangnya jumlah seniman yang menerima perubahan dengan yang tidak menerima perubahan (para seniman yang mempertahankan tradisi atau pakem) sehingga para seniman yang tidak dapat mengikuti perubahan zaman ditinggalkan oleh masyarakat pendukungnya.

Perubahan dalam seni pertunjukan berimbas pula terhadap keberadaan tepak kendang jaipongan. Beragam tepak kendang yang telah direkam dalam kaset akan berbeda hasilnya ketika tepak kendang tersebut digunakan di panggung. Di panggung pertunjukan, pola kendang jaipongan karya Suwanda tidak hanya digunakan dalam satu lagu seperti aslinya, namun dapat diaplikasikan ke dalam lagu yang berbeda sesuai dengan kebiasaan penari. Dapat diberikan contoh di sini yaitu: pola tepak kendang Banda Urang, bisa digunakan untuk lagu Wangsit Siliwangi, pola tepak Seunggah bisa digunakan untuk lagu Ucing-Ucingan, pola tepak Késér Bojong bisa digunakan dalam lagu Bayubayu. Hal ini mempunyai arti bahwa pola dan ragam tepak kendang jaipongan karya Suwanda dapat berubah setelah digunakan oleh masyarakat. Telah terjadi transformasi tepak kendang jaipongan di berbagai daerah terutama setelah dikuasai oleh para pengendang. Proses transformasi yang dimaksud menurut Mardimin (1994: 11-25) adalah perubahan paradigma, cara pandang, pola pikir serta cara mengatasi masalah termasuk pula perubahan konsep, bentuk, fungsi, dan sifat melalui 
proses secara menyeluruh.

Proses transformasi tepak kendang jaipongan terjadi karena ada daya tarik para seniman terhadap pola tepak kendang jaipongan yang diciptakan oleh Suwanda. Para seniman Jawa Barat dan sekitarnya banyak yang meniru pola-pola tepak kendang hasil karya Suwanda melalui berguru, belajar di sekolah seni, atau belajar dari kaset yang beredar di pasaran. Para seniman ada yang secara langsung belajar dari Suwanda dan ada pula yang belajar dari orang lain yang sudah bisa bahkan belajar dengan mendengarkan kaset. Melalui proses ini maka ragam tepak kendang jaipongan semakin menyebar di setiap pelosok daerah serta mengisi perkembangan karawitan Sunda. Kondisi ini memungkinkan untuk terjadi perpindahan dan perubahan pada generasi berikutnya setelah Suwanda. Pada saatnya tidak mengherankan seandainya beragam tepak kendang jaipongan pada masa Suwanda berbeda berbagai motifnya dengan beragam tepak kendang jaipongan pada masa sekarang.

Kendang jaipongan mengalami perubahan akibat adanya tuntutan masyarakat dan kreativitas para seniman. Menurut Boskoff (1964:140-155) capaian perkembangan merupakan akibat dari peminjaman ataupun transkulturasi kreativitas independen dari luar lingkup wilayahnya dan memengaruhi proses perubahan yang terjadi. Perubahan itu adalah inovasi gagasan dan nilai, teknik-teknik, atau aplikasi-aplikasi baru dalam teknologi, bahkan juga di dalam seni. Beberapa persoalan yang muncul dalam masyarakat mencoba mengatasi probelamatika sebagai upaya pengembangannya. Hal ini justru memunculkan inovasi-inovasi baru sebagai faktor internal yang lahir dari masyarakat yang kreatif.

Kehadiran unsur-unsur baru tersebut tidak berarti bahwa unsur-unsur yang ada sebelumnya hilang sama sekali namun antara unsur lama dengan unsur baru dapat saja hidup berdampingan, berbaur, atau bahkan tumpang tindih (Holt, 19967:3).

\section{Jenis-Jenis Perubahan Tepak Kendang}

Keadaan di atas menunjukkan telah terjadi perubahan paradigma, cara pandang, pola pikir termasuk pula perubahan konsep dan fungsi yang terdapat dalam tepak kendang jaipongan. Tepak kendang jaipongan yang pada awalnya untuk mengiringi tari jaipongan sebagai seni apresiasi telah berubah fungsi menjadi seni untuk hiburan. Hal ini berdampak terhadap hasil garapan para seniman dalam tepak kendang jaipongan. Beragam tepak spontanitas (improvisasi) sangat mewarnai masa ini karena penari bukan lagi penari terlatih, melainkan penonton (participant) sebagai penikmat atau pelaku tarinya. Ciri khas lainnya adalah motif mincid sangat mewarnai sehingga tidak mengherankan seandainya motif-motif mincid tepak kendang jaipongan sangat kaya dan variatif.

Perubahan yang paling signifikan dalam tepak kendang jaipongan adalah dalam struktur. Struktur tepak kendang jaipongan pada masa sekarang lebih simple dan banyak berolah dalam motif mincid. Pada umumnya, struktur tepak kendang jaipongan setelah sampai pada bagian mincid, tidak pernah kembali ke bagian bukaan seperti masa Suwanda. Hal ini dapat dicontohkan sebagai berikut bahwa struktur tepak kendang yang umum $\mathrm{A}, \mathrm{B}, \mathrm{C}, \mathrm{D}$, C2, D2, D3, C3, C4, D4, D5, C5, C6, D6, E ....dst berubah menjadi $A, B, C, D, C 1, D 1, D 2$, D3, D4, D5, D6, E.........dst (A untuk tepak pangkat, B tepak pangjadi, C tepak bukaan, D tepak mincid, E tepak ngeureunekeun). Nampak bahwa D1, D2, ...dst merupakan pengolahan beragam motif tepak kendang dalam bagian mincid.

Perubahan lain dalam tepak kendang jaipongan adalah dalam dinamika. Dinamika karawitan jaipongan sangat terasa, banyak terjadi penonjolan dalam garapan terutama yang dihasilkan dari tepakan kendang. Hal ini yang menimbulkan tepak kendang jaipongan lebih dinamis, tidak menjenuhkan bahkan di dalamnya terjadi dialog-dialog musikal yang diwujudkan oleh tepak kendang, gending, dan vokal pesinden. Munculnya dinamika salah satunya berawal dari adanya kerja sama antara koreografer dengan penata karawitan. Ttempo tepak kendang pada masa Suwanda masih dapat diikuti oleh siapa pun yang mempelajari tepak kendang jaipongan. Berbeda pada masa sekarang temponya lebih cepat sehingga garapan-garapannya lebih rumit, maka perlu keahlian khusus untuk memainkan tepak kendang jaipongan. 
Pada umumnya embat (irama) yang digunakan dalam karawitan jaipongan adalah embat dua wilet. Pada perkembangannya, embat dua wilet dianggap sudah menjadi biasa di dalam iringan karawitan jaipongan. Para seniman berusaha mencari sebuah alternatif untuk menembangkan nilainilai kreativitasnya dalam karawitan jaipongan. Embat yang digunakan tidak hanya embat dua wilet, tetapi juga berkembang menjadi embat opat wilet (embat lalamba) yang biasa digunakan utnuk mengiringi lagu-lagu ageung. Garapan dalam embat ini tentunya memiliki tantangan tersendiri karena selain belum lazim digunakan dalam karawitan jaipongan, juga memiliki banyak kesulitan dalam hal garapannnya. Nilai-nilai kerumitan inilah ternyata menjadi sebuah tantangan bagi para seniman dalam berkreativitas sehingga garapan karawitan jaipongan terutama tepak kendangnya menjadi tren yang membutuhkan keterampilan luar biasa. Oleh karena itu berkembanglah garapan jaipongan dengan menggunakan lagu-lagu ageung sebagai pijakannya sehingga bermunculan polapola baru di antaranya Lagu Udan Mas, Kulu-Kulu Bem, Kastawa, dan Tablo.

Masyarakat Jawa Barat termasuk masyarakat yang terbuka terhadap perubahan zaman. Dampak dari sikap terbuka terhadap karya seni nampak dalam perubahan motif tepak kendang jaipongan. Motif tepak kendang jaipongan semakin kaya, variatif terutama dalam motif-motif mincid. Banyak terlahir motif baru hasil karya generasi muda baik dalam bagian intro, pangkat, pengjadi, bukaan, mincid, maupun dalam tepak ngeureunkeun.

Setelah digunakan oleh masyarakat selama tiga puluh tahun lebih maka pola tepak kendang jaipongan Suwanda pada masa sekarang telah mengalami proses "buang”. Terdapat banyak motif tepak kendang jaipongan Suwanda yang tidak lagi digunakan oleh para seniman pada masa sekarang. Tepak kendang jaipongan terutama motifmotif tepaknya mengalami suatu masa di mana masyarakat tidak menggunakannya lagi. Kondisi ini terjadi karena sudah tidak dibutuhkannya motifmotif tepak kendang oleh masyarakat terutama para seniman (Haryono, 2008: 132).

Baik secara bentuk atau rangka tepak kendang jaipongan tidak mengalami perubahan meliputi pangkat, pangjadi, bukaan, mincid dan ngeureunkeun maka dalam ragam tepak sudah banyak yang hilang pada generasi sekarang. Tepak kendang jaipongan yang sekarang ada sebenarnya ragam tepaknya sudah semakin sedikit dibandingkan dulu ketika diciptakan oleh Suwanda. Tepak kendang jaipongan telah terjadi kemiskinan motif atau ragam tepak, misalnya struktur tepak yang dulunya A, B, C, D, $\mathrm{E}$, dan berulang ke $\mathrm{A}$ lagi, sekarang mungkin hanya A sampai $\mathrm{C}$ tanpa ada pengulangan. Pada masa sekarang, para pengendang banyak menghasilkan motif baru dan mengolah motif mincid dalam iringan tari sesuai dengan kebutuhan garapannya.

Berdasarkan pemaparan tersebut maka hilangnya beragam tepak kendang jaipongan karya Suwanda, salah satunya diakibatkan oleh lebih mendominasinya fungsi seni untuk pasar daripada seni untuk seni. Hal ini dapat dicontohkan dalam ragam tepak kendang jaipongan Suwanda yang sudah tidak digunakan lagi oleh para pengendang di antaranya ragam tepak Écék, ragam tepak Képrét, ragam tepak Kanyay, ragam tepak Kuntul Liwat, ragam tepak Mincid Kendor, ragam tepak Balatak, ragam tepak Mincid Gobéd, dan pola pengulangan.

Karawitan jaipongan pada masa sekarang (tahun 2012) telah mengalami perkembangan yang luar biasa. Perkembangan karawitan jaipongan terutama dalam penggalian lagu-lagu ageung yang tidak lazim digunakan dalam jaipongan, sekarang mulai digali oleh para generasi muda. Hal ini merupakan terobosan baru yang luar biasa. Tepak kendang jaipongan Suwanda yang kaya dan variatif mengalami kemiskinan yang luar biasa oleh para pengendang sekarang dan hal ini sangat disayangkan sekali. Banyak ragam tepak dan variasi yang hilang karena mendominasinya fungsi jaipongan untuk melayani pasar dibandingkan untuk kepentingan seni itu sendiri.

Menurut Suwanda, 'Jaipongan ayeuna tos leupas tina tetekon, melenceng tebih pisan, melenceng kana sendratari, tos janten sendra tari, teu apal balik teu bisa balik, leupas tina aturan". (Jaipongan sekarang sudah keluar dari pakem, melenceng sangat jauh bahkan ke sendratari, sudah jadi sendratari, tidak tahu kembali, dan lepas dari aturan (Wawancara dengan Suwanda, 29 Mei 2012). 
Motif tepak kendang jaipongan mengalami perubahan lebih khusus pula terhadap motif-motif tepak kendang jaipongan hasil karya Suwanda. Beragam tepak kendang jaipongan yang dibuat oleh Suwanda dan direkam dalam bentuk kaset, mengalami banyak perubahan ketika digunakan oleh para seniman saat pentas di panggung pertunjukan. Para seniman mencoba menafsir sendiri beragam tepak kendang jaipongan Suwanda sesuai dengan interpretasi masing-masing terutama ketika digunakan untuk mengiring tarian jaipongan. Hal ini muncul karena kebutuhan yang terjadi di lapangan. Para penari dan pengendang berusaha memunculkan nilai kreativitas masing-masing meskipun dalam lagu yang sudah baku (umum) di masyarakat. Para seniman selalu berusaha mencari celah-celah dalam lagu jaipongan untuk memunculkan kreativitas individunya. Dengan demikian, meskipun lagu, bentuk, dan strukturnya sama, secara motif di dalamnya mengalami banyak perbedaan. Para seniman membutuhkan sebuah alternatif garapan yang dapat mewakili dan memenuhi rasa musikalitasnya.

Berikut ini dituliskan contoh perubahan ragam tepak kendang jaipongan karya Suwanda dalam Lagu Daun Pulus Késér Bojong yang muncul dari para seniman dan banyak digunakan di panggung pertunjukan.

\section{Ragam Tepak Mincid Uplek}

Pola dari Suwanda dalam kaset rekaman.

Matra ke-1 masuk lagu, garap kendang dikosongkan

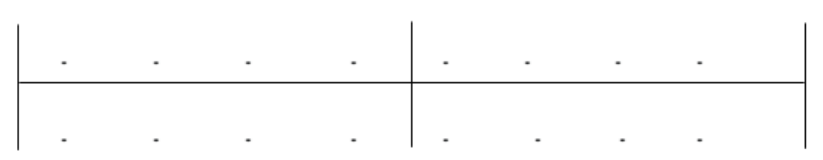

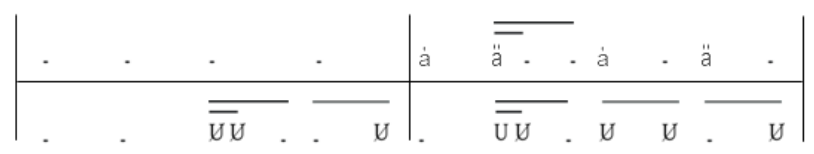
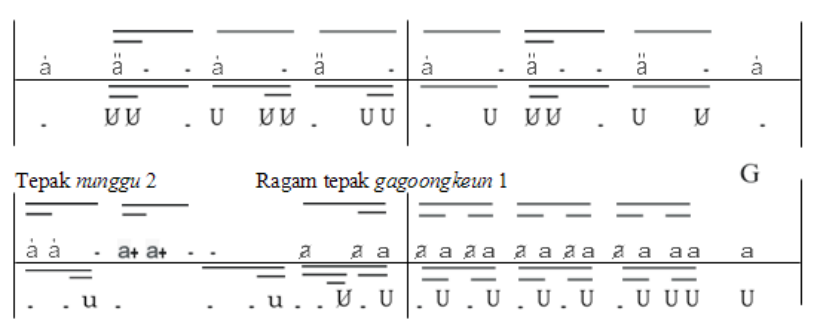

Sumber: Kaset audio Daun Pulus Késér Bojong, 2005 Notasi : Asep Saepudin
Tepak mincid uplek tersebut diganti sebagai berikut.

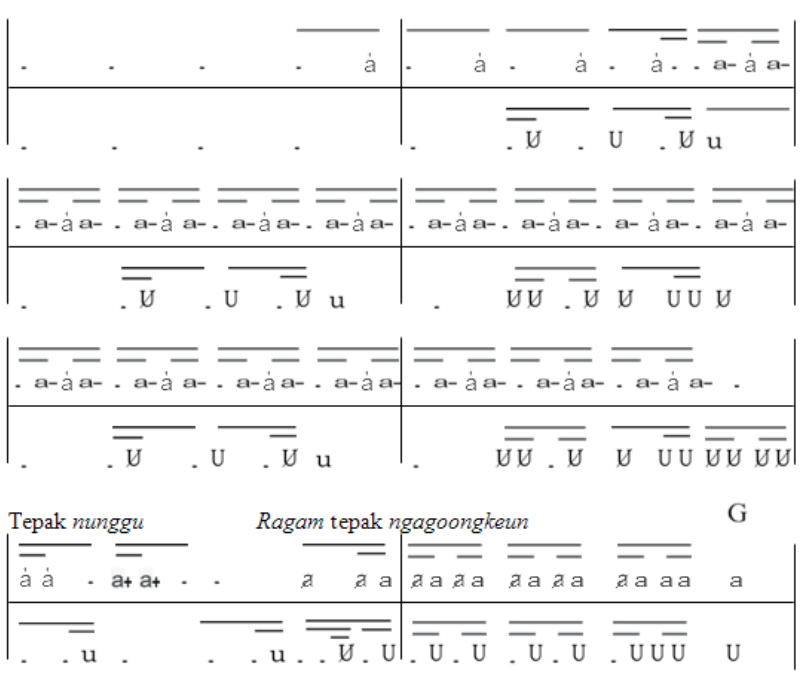

Sumber: Yaya Suryadi

Notasi : Asep Saepudin

\section{Simpulan}

Terjadinya perubahan beragam tepak kendang jaipongan seperti telah diuraikan tidak serta merta terjadi, namun telah melalui perjalanan panjang sesuai dengan rentang waktu yang dijalaninya. Hadirnya faktor internal (yang datang dari diri para seniman) dan faktor eksternal (yang datang dari luar) sebagai usaha untuk menyesuaikan dengan zaman dan tuntutan pasar, mengakibatkan berubahnya beragam tepak kendang jaipongan. Beberapa faktor penyebab terjadinya perubahan dan kepunahan motif-motif tepak kendang jaipongan Suwanda di antaranya hadirnya para pengendang muda, munculnya kreativitas baru tepak kendang jaipongan dari para seniman, munculnya motif-motif tepak kendang bajidoran yang banyak improvisasi sehingga banyak ditiru oleh para seniman, teknologi yang semakin canggih baik alat rekaman maupun sound system, serta tuntutan masyarakat (pasar) yang mengakibatkan berubahnya fungsi jaipongan dari fungsi apresiasi menjadi fungsi hiburan bagi masyarakat.

\section{Ucapan Terima Kasih}

Terima kasih penulis ucapkan kepada keluarga besar Bapak H. Suwanda yang telah menerima penulis selama melakukan penelitian dan telah 
memberi data serta informasi tentang bahan penelitian. Mudah-mudahan berbagai data tentang perubahan dan perkembangan tepak kendang jaipongan dapat bermanfaat bagi perkembangan keilmuan karawitan.

\section{Kepustakaan}

Boskoff, Alvin. 1964. "Recent Theories of Social Change" dalam Werner J. Chanman dan Alfin Boskoff (ed). Sociology and History: Theory and Research. London: The Free Press of Glencoe.

Brandon, James R. 2003. Jejak-Jejak Seni Pertunjukan di Asia Tenggara. Bandung: P4ST UPI.

Haryono, Timbul. 2008. Seni Pertunjukan dan Seni Rupa dalam Perspektif Arkeologi Seni. Surakarta: ISI Press.

Holt, Claire. 1967. Art in Indonesia: Continuitis and Change. Ithaca: Cornell University Press.

Kartodirdjo, Sartono. 1992. Pendekatan Ilmu Sosial dalam Metodologi Sejarah. Jakarta: Gramedia Pustaka Utama.

Mardimin, Johanes (Ed.). 1994. Jangan Tangisi Tradisi: Transformasi Budaya Menuju Masyarakat Indonesia Modern. Yogyakarta: Kanisius.

Mulyadi, Tubagus. 2003. "Gugum Gumbira Maestro Tari Jaipongan: Sebuah Biografi." [Tesis] Program Pengkajian Seni Pertunjukan dan Seni Rupa, Universitas Gadjah Mada Yogyakarta.
Narawati, Tati dan R.M. Soedarsono. 2005. Tari Sunda: Dulu, Kini, dan Esok. Bandung: Pusat Penelitian dan Pengembangan Pendidikan Seni Tradisional Universitas Pendidikan Indonesia (P4STU PI).

Saepudin, Asep. 2010. "Kreativitas Suwanda dalam Tepak Kendang Kendang Jaipongan di Jawa Barat." [Tesis] Program Pengkajian Seni Pertunjukan dan Seni Rupa, Universitas Gadjah Mada Yogyakarta.

Soepandi, Atik dkk. 1999. Ragam Cipta: Mengenal Seni Pertunjukan Daerah Jawa Barat. Bandung: CV Sampurna.

Tim Penyusun Kamus Pusat Pembinaan dan Pengembangan Bahasa. 2005. Kamus Besar Bahasa Indonesia. Jakarta: Balai Pustaka.

\section{Sumber Audio}

Kaset audio jaipongan berjudul "Daun Pulus Késér Bojong” produksi Jugala Record, No. 01. 201. 347. 0-422 080/2005.

Kaset audio jaipongan berjudul "Seunggah" produksi Jugala Record, No. 01. 201. 347. 0-412 000/2005.

\section{Informan}

Suwanda, 60 tahun. Seniman pencipta tepak kendang jaipongan, pangrawit Jugala Group tahun 1980-an, pimpinan jaipongan "Suwanda Group" dari Karawang. 